\title{
Factors associated with the distribution of natural Toxoplasma gondii infection among equids in Northeastern Brazil
}

\author{
Fatores associados à distribuição da infecção por Toxoplasma gondii em equídeos naturalmente \\ infectados no Nordeste do Brasil
Alexandre Dias Munhoz ${ }^{1 *}$ (1); Monia Andrade Souza ${ }^{1}$; Sonia Carmen Lopo Costa ${ }^{1}$; Jéssica de Souza Freitas'; Aísla Nascimento da Silva ${ }^{1}$; Luciana Carvalho Lacerda ${ }^{1}$; Rebeca Dálety Santos Cruz ${ }^{1}$; George Rêgo Albuquerque'; Maria Julia Salim Pereira ${ }^{2}$

${ }^{1}$ Departamento de Ciências Agrárias e Ambientais, Universidade Estadual de Santa Cruz - UESC, Salobrinho, Ilhéus, BA, Brasil ${ }^{2}$ Departamento de Parasitologia Animal, Universidade Federal Rural do Rio de Janeiro - UFRRJ, Seropédica, RJ, Brasil

Received December 19, 2018

Accepted April 11, 2019

\begin{abstract}
The aim of this study was to determine the frequency and factors associated with Toxoplasma gondii in naturally infected equids in northeastern Brazil. Serum samples from 569 equids (528 horses, 8 mules and 33 donkeys) were subjected to the indirect fluorescent antibody test. Generalized linear models were used to evaluate associated factors. Among the 569 animals sampled, 118 (30.6\%) living in rural areas and $14(26.42 \%)$ in urban areas were seropositive ( $p>0.05$ ). Seropositive animals were observed on $95 \%$ of the farms and in all the municipalities. Donkeys/mules as the host, presence of domestic cats and rats on the farm, ingestion of lagoon water and goat rearing remained in the final model as factors associated with infection. Preventive measures such as avoiding the presence of domestic cats close to rearing areas, pastures and sources of water for the animals should be adopted. The wide-ranging distribution of positive animals also indicated that infection in other domestic animals and in humans, through the contaminated environment, was possible. It should be highlighted that there was the possibility that donkeys and mules would continue to have detectable titers for longer, thus explaining the prevalence found. Further studies are needed to confirm this possibility.
\end{abstract}

Keywords: Toxoplasmosis, horse, serology, risk factors.

\section{Resumo}

O objetivo deste estudo foi determinar a frequência e os fatores associados a Toxoplasma gondii em equídeos naturalmente infectados no Nordeste do Brasil. Amostras de soro de 569 equídeos (528 cavalos, 8 asnos e 33 muares) foram submetidas a reação de imunofluorescência indireta. Modelos lineares generalizados foram utilizados na avaliaçấo dos fatores associados. Dos 569 animais amostrados, 118 (30,6\%) soropositivos eram de área rural e 14 (26,42\%) perteciam a áreas urbanas ( $>00,05)$. Observaram-se animais soropositivos em $95 \%$ das fazendas e em todos os municípios. Asininos/muares como hospedeiro, presença de gatos domésticos e ratos na fazenda, ingestão de água de lagoa e criação de caprinos permaneceram no modelo final como fatores associados à infecção. Medidas de prevençáo, como evitar a presença de gatos domésticos próximos aos locais de criação, de pastejo e fontes de água dos animais, devem ser adotadas. A ampla distribuição de animais positivos sinaliza a possibilidade de infecção também em outros animais domésticos, bem como em humanos pelo ambiente contaminado. Ressalta-se a possibilidade de que asininos e muares permaneçam com títulos detectáveis por mais tempo, justificando a prevalência encontrada, sendo necessários estudos para confirmar este possibilidade.

Palavras-chave: Toxoplasmose, cavalo, sorologia, fatores de risco.

\section{Introduction}

Toxoplasmosis is a zoonosis caused by the protozoon Toxoplasma gondii, which has cosmopolitan distribution. Infection by this agent affects 70 to 95\% of the world's population (BRASIL, 2010).

*Corresponding author: Alexandre Dias Munhoz. Universidade Estadual de Santa Cruz, Rodovia Ilhéus Itabuna, Km 16, Campus Soane Nazaré de Andrade, CEP 45662-900, Salobrinho, Ilhéus, BA, Brasil. e-mail: munhoz@uesc.br
Herbivores mainly become infected while grazing, through ingestion of oocysts that have sporulated in the environment and, to a lesser extent, through vertical transmission (DUBEY, 2008, 2010).

In the European Union, the average consumption of horse meat is 110,000 tons per year (FAO, 2013). Although horses are 
considered to be resistant to toxoplasmosis, the possibility that horse meat can be a source of infection for cats and other animals in zoos, as well as for human beings, has already been proven (AL-KHALIDI \& DUBEY, 1979; DUBEY \& DESMONTS, 1987; MARQUES et al., 1998; SHAAPAN \& GHAZY, 2007; POMARES et al., 2011; EVERS et al., 2013)

Seroepidemiological studies on horses have demonstrated that $T$. gondii infection has cosmopolitan distribution and that its prevalence may range from 1 to $71.2 \%$ (JAKUBEK et al., 2006; HAJIALILO et al., 2010; LOPES et al., 2013). Between different Brazilian states, large variations in the prevalence of T. gondii can be observed, with results ranging from 1.5 to $41.53 \%$, regarding positivity among animals (VIDOTTO et al., 1997; MENDONÇA et al., 2001).

The differences in positivity that are found in different places may be associated with epidemiological factors such as different types of rearing, stable hygiene and different types of food (TENTER et al., 2000). These factors make it important to identify the possible risk factors associated with a given region. Furthermore, the sensitivity and specificity of serological tests, geographical areas and climatic conditions and the presence of cats close to rearing areas or sources of food or water may interfere with positivity for infection.

Because of the way in which infection occurs, positivity for T. gondii among horses can be seen as an indicator of environmental contamination by sporulated oocysts. This may therefore indirectly assist in characterizing areas as presenting greater or lesser contamination.
Thus, the present study had the objectives of ascertaining the distribution of $T$. gondii infection and evaluating factors associated with this, among equids that acquired this infection naturally, in the Ilhéus-Itabuna microregion of the state of Bahia, northeastern Brazil.

\section{Materials and Methods}

\section{Study area and sample population}

This study was conducted in accordance with the standards established by the Brazilian College of Animal Ethics and Welfare. The research proposal was approved by the Committee for Animal Research Ethics (protocol no. 002/2013) at Santa Cruz State University, Ilhéus, BA, Brazil. Data were collected between August 2013 and December 2014 in the microregion of Ilhéus-Itabuna, state of Bahia, northeastern Brazil. This geographical region is part of the mesoregion of Southern Bahia and has an estimated equid population of 90,974 animals.

The study area was located in the Atlantic forest. The annual average rainfall is $1445 \mathrm{~mm}$, with relative humidity of $80 \%$, and temperature of $24^{\circ} \mathrm{C}$ (BRASIL, 2010). Five municipalities in this mainly rural microregion were selected for this study, and were ranked according to the size of their equid population, as

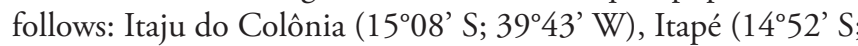
$\left.39^{\circ} 25^{\prime} \mathrm{W}\right)$, Ibicaraí (14²51' S; $\left.39^{\circ} 35^{\prime} \mathrm{W}\right)$, Santa Cruz da Vitória

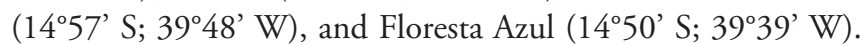
The municipality of Itabuna $\left(15^{\circ} 8^{\prime} \mathrm{S} ; 39^{\circ} 43^{\prime} \mathrm{W}\right)$, which is a mostly urban area, was also included in this study (Figure 1).
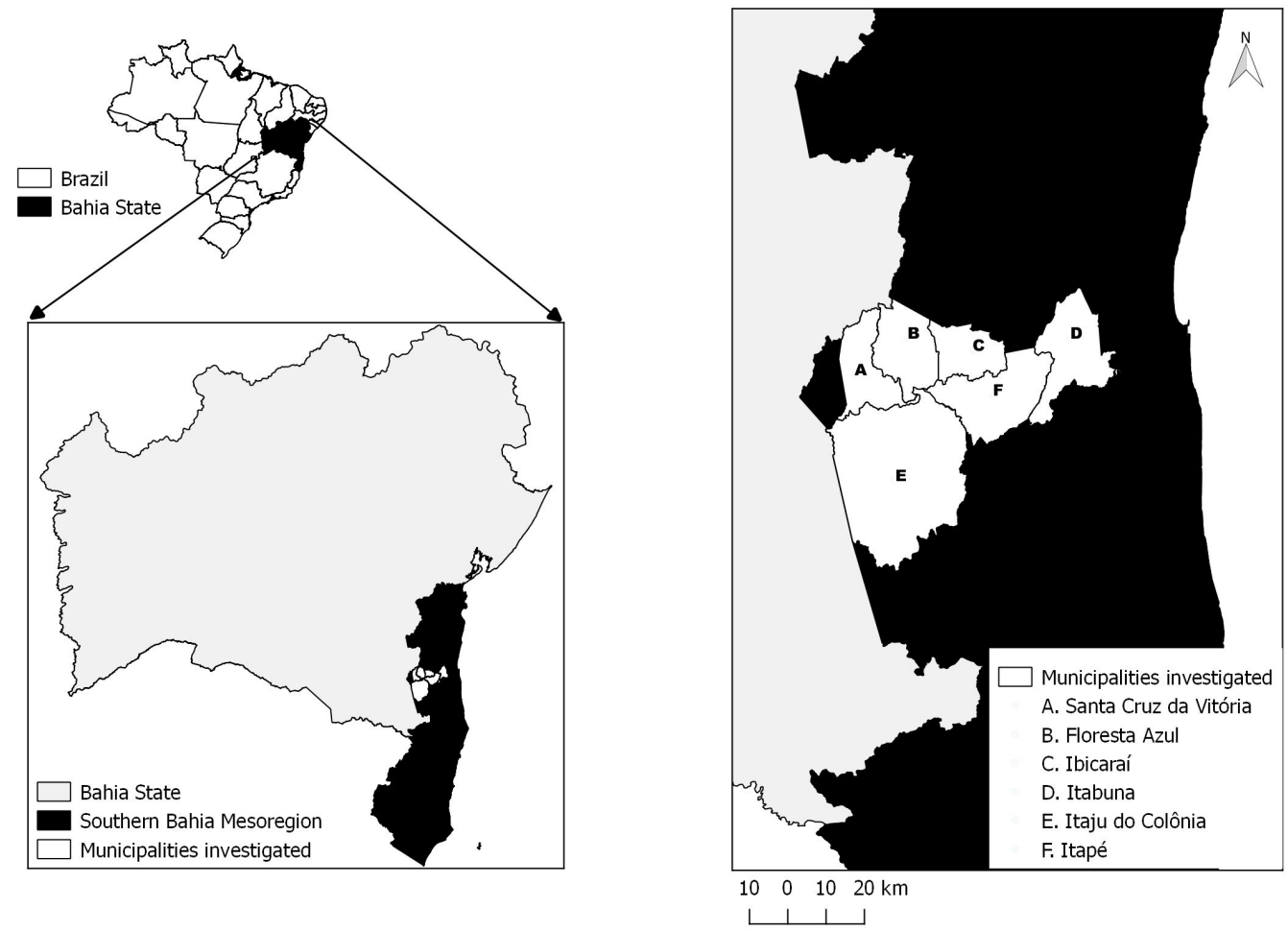

Figure 1. Location of the study area, which included the municipalities of Itaju do Colônia, Santa Cruz da Vitória, Itapé, Ibicaraí, Floresta Azul, and Itabuna, Bahia, Brazil. 
Animals, farms and municipalities were selected based on their convenience. The numbers of animals per municipality were proportional to their equid populations. Blood samples were collected from 569 equids (528 horses, 8 mules and 33 donkeys); 516 out of these 569 equids were living on 20 rural farms; 53 horses out of these 569 equids were living in urban areas and were used by mounted police, or to draw coaches, or for horseback riding.

To evaluate potential risk factors, information regarding signalment (species, age and gender), farm characteristics and management (place where animal was kept, i.e. in a stable or elsewhere; and contact with other animal species) were obtained through semi-structured interviews with handlers (staff) or owners. The interviews were always conducted by the same researcher.

\section{Sample collection and processing}

A $10 \mathrm{~mL}$ blood sample was collected from each animal by means of jugular venipuncture using a disposable needle $(25 \times 8 \mathrm{~mm})$ that was connected to a vacuum tube without anticoagulant. The tubes containing the samples were centrifuged for 10 minutes at $699 g$ and the serum was poured into Eppendorf tubes and frozen at $-20{ }^{\circ} \mathrm{C}$ for subsequent serological tests.

The serum samples were tested for antibodies to $T$. gondii by means of the indirect fluorescent antibody test using the $\mathrm{RH}$ parasite strain. Commercially available FITC-labeled anti-horse IgG (F-7759, Sigma-Aldrich St. Louis, MO, USA) was used as a secondary antibody at a dilution of 1:32. The serum dilution threshold for positivity was set at 1:64 (GARCIA et al., 1999; GHAZY et al., 2007; EVERS et al., 2013). The controls (positive and negative) were kindly provided by the Immunoparasitology Laboratory of the State University of São Paulo "Júlio Mesquita Filho", UNESP, in Jaboticabal, São Paulo.

\section{Statistical analysis}

The variables were categorized for the purposes of statistical modeling as follows: species (horse or donkey + mule); age, in the form of age ranges, i.e. young ( $\leq 3$ years), adult ( $>3$ and $<12$ years) or senior ( $\geq 12$ years); sex (male or female); presence of cats on the farm (yes or no); presence of wild felids on the farm (yes or no); equids kept in a stable (yes or no); equids had contact with sheep (yes or no); equids had contact with goats (yes or no); equids had contact with poultry (yes or no); equids had contact with cattle (yes or no); presence of rats on the farm (yes or no); presence of toxic plants in the pastures (yes or no); equids were drinking water from a weir (yes or no); equids were drinking water from a river (yes or no); equids were drinking water from a lagoon (yes or no); and equids were eating food that had been stored on the farm (yes or no). Positive results from serological tests for T. gondii (yes or no) were considered to be an outcome variable. Donkeys and mules were inserted into a single category due to the low number of animals.

Blood samples from animals in urban areas were only collected in the municipality of Itabuna. A total of 53 horses were sampled, including those used by the mounted police, or to draw coaches, or for horseback riding. These animals were excluded from the modeling because of the different management practices that had been applied to these horses and were utilized only to compare frequency distributions to toxoplasmosis between animals living in rural and urban areas.

Generalized linear models with binomial distribution were used to perform bivariate and multivariate analyses. Because of the possibility of clusters, intraclass correlation coefficients (ICCs) were calculated. Null models (STARKWEATHER, 2010) were estimated to obtain ICCs for the variables municipality and farm due to the possibility of observations of animals from the same municipality and or farm being correlated, forming clusters (DOHOO et al., 2003). In cases of cluster formation, the variables tested were considered random and generalized linear mixed models were used for the analyses.

The modeling strategy used in the multivariate analyses was backward, i.e. all variables were initially included in the model. Starting from this initial model, variables were selected at each step based on the Wald test, until the most parsimonious model that best explained the outcome was obtained. The significance level for variables to remain in the final model was set at $5 \%$. The Akaike information criterion (AIC) was used to evaluate the fit of the models. Frequency distributions between animals living in rural areas and animals living in urban areas were compared using the chi-square test.

Odds ratios (OR) and their respective 95\% confidence intervals (CI) were calculated based on the regression coefficients that had been estimated through the models. Statistical calculations were performed using the R software, version 3.2.5 for Windows (R DEVELOPMENT CORE TEAM, 2016), through the lmer4 package (BATES et al., 2015), version 1.1-12.

\section{Results}

A total of $30.62 \%(158 / 516$; CI: $26.71-34.83 \%)$ of the horses in the rural area were seroreactive, with titers ranging from 64 to 4096 (Table 1). The horses presented positivity of $27.36 \%$ (130/475; CI: $23.45-31.66 \%)$, the donkeys 72.73\% (24/33; CI: $54.48-86.7 \%)$ and the mules 50\% (4/4; CI: $15.7-84.3 \%)$. At least one seroreactive animal was identified on $95 \%(19 / 20)$ of the farms, and the positivity on the farms ranged from 8.3 to $56.25 \%$. Positive animals were identified in every municipality (Table 1 ). In table 2 are observed the results of the association between each of the explanatory variables with the outcome variable. The ICCs per municipality $(5.7 \%)$ and per farm (6.2\%) indicated that cluster formation existed, thus, generalized linear mixed models were used. The results of the associations in the full model are observed in Table 3. The donkey/mule species together, ingestion of lagoon water by the horses, presence of cats and rats and absence of goat rearing on the farm were identified as possible risk factors (Table 4). Among the horses in the urban area, seropositivity of $26.42 \%$ was observed (14/53; CI: 15.3-40.3\%). This was not significantly difference from the positivity found in the rural area $(\mathrm{p}>0.05)$. 
Table 1. Distribution of equidae serology results to Toxoplasma gondii, and their respective titrations, from the Ilhéus-Itabuna microregion, in the state of Bahia, Brazil.

\begin{tabular}{|c|c|c|c|c|c|c|c|c|c|}
\hline \multirow{3}{*}{ Municipality } & \multirow{3}{*}{$\begin{array}{l}\text { Total of } \\
\text { animals }\end{array}$} & \multicolumn{8}{|c|}{ Serology } \\
\hline & & \multirow{2}{*}{$\begin{array}{c}\text { Negative } \\
\% \\
\end{array}$} & \multicolumn{6}{|c|}{ Titration } & \multirow{2}{*}{$\begin{array}{c}\text { Positive } \\
\% \\
\end{array}$} \\
\hline & & & 64 & 128 & 256 & 512 & 1024 & 4096 & \\
\hline Floresta Azul & 98 & 78 & 10 & 2 & 4 & 2 & 2 & 0 & 20.4 \\
\hline Ibicaraí & 80 & 44 & 13 & 12 & 8 & 2 & 1 & 0 & 45 \\
\hline Itaju do Colônia & 186 & 140 & 26 & 15 & 4 & 1 & 0 & 0 & 24.7 \\
\hline Itapé & 67 & 50 & 7 & 8 & 1 & 0 & 0 & 1 & 25.37 \\
\hline Santa Cruz da Vitória & 85 & 46 & 16 & 14 & 8 & 1 & 0 & 0 & 45.88 \\
\hline Total & 516 & 358 & 72 & 51 & 25 & 6 & 3 & 1 & 30.62 \\
\hline
\end{tabular}

Table 2. Generalized linear mixed models for factors associated with Toxoplasma gondii infections in naturally infected equidae from the Ilhéus-Itabuna microregion, in the state of Bahia. Bivariate analysis.

\begin{tabular}{|c|c|c|c|c|c|c|}
\hline \multirow{3}{*}{ Variable } & \multicolumn{4}{|c|}{ Equids } & \multirow{3}{*}{$\begin{array}{l}\text { Odds ratio } \\
\left(95 \% \mathrm{CI}^{*}\right)\end{array}$} & \multirow{3}{*}{ P value } \\
\hline & \multicolumn{2}{|c|}{ Positive } & \multicolumn{2}{|c|}{ Negative } & & \\
\hline & $\mathbf{n}$ & $\%$ & $\mathbf{n}$ & $(\%)$ & & \\
\hline \multicolumn{7}{|l|}{ Age range } \\
\hline Young (ref) & 27 & 31.4 & 59 & 68.6 & - & \\
\hline Adult & 77 & 30.7 & 174 & 69.3 & $1.00(0.57-1.75)$ & 0.99 \\
\hline Senior & 54 & 30.2 & 125 & 69.8 & $1.13(0.62-2.07)$ & 0.69 \\
\hline \multicolumn{7}{|l|}{ Species } \\
\hline Equine (ref) & 130 & 27.7 & 345 & 62.3 & - & \\
\hline Donkey or mule & 28 & 68.3 & 13 & 31.7 & $4.85(2.20-10.74)$ & $<0.001$ \\
\hline \multicolumn{7}{|l|}{ Gender } \\
\hline Female (ref) & 114 & 30.4 & 261 & 69.6 & - & \\
\hline Male & 44 & 31.2 & 97 & 68.8 & $0.67(0.33-1.34)$ & 0.25 \\
\hline \multicolumn{7}{|l|}{ Equid drink water of weir } \\
\hline Yes & 144 & 3 & 321 & 69 & $1.55(0.61-3.93)$ & 0.36 \\
\hline No (ref) & 14 & 27.5 & 37 & 72.5 & - & \\
\hline \multicolumn{7}{|l|}{ Equid drink water of river } \\
\hline Yes (ref) & 58 & 29 & 142 & 71 & - & \\
\hline No & 100 & 31.6 & 216 & 68.4 & $1.1(0.61-2.03)$ & 0.73 \\
\hline \multicolumn{7}{|c|}{ Equid drink water of lagoon } \\
\hline Yes & 26 & 30.6 & 59 & 69.4 & $1.41(0.56-3.6)$ & \\
\hline No (ref) & 132 & 30.6 & 299 & 69.4 & - & \\
\hline \multicolumn{7}{|c|}{ Presence of cats in the farm } \\
\hline Yes & 134 & 33.8 & 263 & 66.2 & $2.4(1.05-5.48)$ & 0.04 \\
\hline No (ref) & 24 & 20.2 & 95 & 79.8 & - & \\
\hline \multicolumn{7}{|c|}{ Presence of wild felids in the farm } \\
\hline Yes & 44 & 29.7 & 104 & 70.3 & $1.55(0.71-3.38)$ & 0.27 \\
\hline No (ref) & 114 & 31 & 254 & 69 & - & \\
\hline \multicolumn{7}{|c|}{ Equid had contact with cattle } \\
\hline Yes (ref) & 133 & 30.4 & 304 & 69.6 & - & \\
\hline No & 25 & 31.6 & 54 & 68.4 & $1.52(0.62-3.77)$ & 0.36 \\
\hline \multicolumn{7}{|c|}{ Equid had contact with sheep } \\
\hline Yes (ref) & 35 & 33 & 71 & 67 & - & \\
\hline No & 123 & 30 & 287 & 70 & $0.70(0.33-1.49)$ & 0.35 \\
\hline \multicolumn{7}{|c|}{ Equid had contact with goat } \\
\hline Yes (ref) & 17 & 28.3 & 43 & 71.7 & - & \\
\hline No & 141 & 30.9 & 315 & 69.1 & $0.88(0.26-2.95)$ & 0.84 \\
\hline \multicolumn{7}{|c|}{ Equid had contact with poultry } \\
\hline Yes (ref) & 142 & 31.8 & 305 & 68.2 & - & \\
\hline No & 16 & 23.2 & 53 & 76.8 & $0.58(0.25-1.34)$ & 0.20 \\
\hline
\end{tabular}

${ }^{*} \mathrm{CI}$ : Confience Interval. 
Table 2. Continued...

\begin{tabular}{|c|c|c|c|c|c|c|}
\hline \multirow{3}{*}{ Variable } & \multicolumn{4}{|c|}{ Equids } & \multirow{3}{*}{$\begin{array}{l}\text { Odds ratio } \\
\left(95 \% \mathrm{CI}^{*}\right)\end{array}$} & \multirow{3}{*}{ P value } \\
\hline & \multicolumn{2}{|c|}{ Positive } & \multicolumn{2}{|c|}{ Negative } & & \\
\hline & $\mathbf{n}$ & $\%$ & $\mathbf{n}$ & $(\%)$ & & \\
\hline \multicolumn{7}{|c|}{ Presence of rats in the farm } \\
\hline Yes & 137 & 33.3 & 274 & 66.7 & $2.1(1.01-4.38)$ & 0.05 \\
\hline No (ref) & 21 & 20 & 84 & 80 & - & \\
\hline \multicolumn{7}{|l|}{ Equid kept in a stable } \\
\hline Yes & 10 & 20.8 & 38 & 79.2 & $0.71(0.32-1.61)$ & 0.42 \\
\hline No (ref) & 148 & 31.6 & 320 & 68.4 & - & \\
\hline \multicolumn{7}{|c|}{ Equid eat food stored on the farm } \\
\hline Yes & 107 & 26.9 & 291 & 73.1 & $0.57(0.25-1.27)$ & 0.17 \\
\hline No (ref) & 51 & 43.2 & 67 & 56.8 & - & \\
\hline \multicolumn{7}{|c|}{ Presence of toxic plants in the pasture } \\
\hline Yes & 73 & 31.6 & 158 & 68.4 & $1.18(0.65-2.15)$ & 0.58 \\
\hline No (ref) & 85 & 29.8 & 200 & 70.2 & - & \\
\hline
\end{tabular}

${ }^{*} \mathrm{CI}$ : Confience Interval.

Table 3. Generalized linear mixed model for factors associated with Toxoplasma gondii infections in equidae from the Ilhéus-Itabuna microregion, in the state of Bahia. Multivariate analysis, full model.

\begin{tabular}{|c|c|c|c|}
\hline \multirow{2}{*}{ Variable } & \multirow{2}{*}{ Category } & Odds Ratio & \multirow{2}{*}{ Pvalue } \\
\hline & & $\left(95 \% \mathrm{CI}^{*}\right)$ & \\
\hline \multirow[t]{3}{*}{ Age range } & Young (ref) & & \\
\hline & Adult & $0.78(0.44-1.40)$ & $>0.05$ \\
\hline & Senior & $0.94(0.50-1.74)$ & \\
\hline \multirow[t]{2}{*}{ Species } & Equin (ref) & & \\
\hline & Donkey or mule & $6.49(2.68-15.74)$ & $\leq 0.001$ \\
\hline \multirow[t]{2}{*}{ Gender } & Fêmea (ref) & & \\
\hline & macho & $1.12(0.60-2.09)$ & $>0.05$ \\
\hline \multirow[t]{2}{*}{ Equid drink water of weir } & Yes & $2.30(0.50-10.52)$ & $>0.05$ \\
\hline & No (ref) & & \\
\hline \multirow[t]{2}{*}{ Equid drink water of river } & Yes (ref) & & \\
\hline & No & $1.19(0.54-2.65)$ & $>0.05$ \\
\hline \multirow[t]{2}{*}{ Equid drink water of lagoon } & Yes & $8.07(1.00-65.33)$ & 0.05 \\
\hline & No (ref) & & \\
\hline \multirow[t]{2}{*}{ Presence of cats in the farm } & Yes & $4.93(1.60-15.15)$ & 0.001 \\
\hline & No (ref) & & \\
\hline \multirow[t]{2}{*}{ Presence of wild felids in the farm } & Yes & $0.53(0.23-1.22)$ & $>0.05$ \\
\hline & No (ref) & & \\
\hline \multirow[t]{2}{*}{ Equid had contact with cattle } & Yes (ref) & & \\
\hline & No & $1.24(0.44-3.52)$ & $>0.05$ \\
\hline \multirow[t]{2}{*}{ Equid had contact with sheep } & Yes (ref) & & \\
\hline & No & $1.77(0.48-6.59)$ & $>0.05$ \\
\hline \multirow[t]{2}{*}{ Equid had contact with goats } & Yes (ref) & & \\
\hline & No & $8.69(1.17-64.30)$ & 0.01 \\
\hline \multirow[t]{2}{*}{ Equid had contact with poultry } & Yes (ref) & & \\
\hline & No & $0.69(0.26-1.85)$ & $>0.05$ \\
\hline \multirow[t]{2}{*}{ Presence of rats in the farm } & Yes & $3.03(1.14-8.07)$ & 0.01 \\
\hline & No (ref) & & \\
\hline \multirow[t]{2}{*}{ Equid kept in a stable } & Yes & $1.21(0.48-3.07)$ & $>0.05$ \\
\hline & No (ref) & & \\
\hline \multirow[t]{2}{*}{ Equid eat food stored on the farm } & Yes & $1.90(0.62-5.77)$ & $>0.05$ \\
\hline & No (ref) & & \\
\hline \multirow{2}{*}{ Presence of toxic plants in the pasture } & Yes & $0.62(0.28-1.35)$ & $>0.05$ \\
\hline & No (ref) & & \\
\hline
\end{tabular}


Table 4. Generalized linear mixed model for factors associated with Toxoplasma gondii infections in equidae from the Ilhéus-Itabuna microregion, in the state of Bahia, Brazil. Multivariate analysis, final model.

\begin{tabular}{|c|c|c|c|}
\hline \multirow{2}{*}{ Variable } & \multirow{2}{*}{ Category } & Odds ratio & \multirow{2}{*}{ Pvalue } \\
\hline & & $\left(95 \% \mathrm{CI}^{*}\right)$ & \\
\hline \multirow[t]{2}{*}{ Species } & Equine (ref) & & \\
\hline & Donkey or mule & $4.21(2.07-8.57)$ & 0.001 \\
\hline \multirow[t]{2}{*}{ Equid had contact with goats } & Yes (ref) & - & \\
\hline & No & $5.09(1.5-17.24)$ & 0.01 \\
\hline \multirow[t]{2}{*}{ Presence of rats in the farm } & Yes & $2.00(1.15-3.46)$ & 0.05 \\
\hline & No (ref) & - & \\
\hline \multirow[t]{2}{*}{ Presence of cats in the farm } & Yes & $3.58(1.76-7.28)$ & 0.001 \\
\hline & No (ref) & - & \\
\hline \multirow[t]{2}{*}{ Equid drink water of lagoon } & Yes & $3.79(1.32-10.87)$ & 0.05 \\
\hline & No (Ref) & - & \\
\hline
\end{tabular}

${ }^{*} \mathrm{CI}$ : Confience Interval; AIC: 604.2.

\section{Discussion}

The Ilhéus-Itabuna microregion has a hot humid climate, which may explain the high frequency and widespread distribution of seropositive horses found in the present study. According to Dubey (2010), herbivore infection is more prevalent in hot climates and humid areas because of better conditions for sporulation and maintenance of viable oocysts in the environment. This widespread distribution could also be seen in the present study through the similar positivity among animals living in rural areas and among those in urban areas. This result differed from what was found by Alvarado-Esquivel et al. (2012), who observed greater positivity among animals living in rural areas. Lastly, the importance of the region's climate can be proven by the low positivity found $(1.5 \%)$ in the municipalities of Jacobina and Jequié (MENDONÇA et al., 2001). Although these municipalities are close to the area of the present study, they have a semi-arid climate with low relative humidity and low levels of rainfall.

Conflicting seropositivity results are found in the literature for T. gondii involving horses, mules and donkeys. Similar to the results from the present study, some previous studies demonstrated higher seropositivity among donkeys and mules than among horses (GARCÍA-BOCANEGRA et al., 2012; SAQIB et al., 2015), or elevated seropositivity in donkeys (EL-GHAYSH, 1998; HARIDY et al., 2010). However, the presence of similar prevalences between horses and donkeys has also been reported (YANG et al., 2013). Since horses are considered to be naturally resistant to $T$. gondii infection (DUBEY, 2010), it is possible that, with the evolution of infection, antibody titers fall below the cutoff point of the serological test, thus making the animals negative in this test (EVERS et al., 2013).

Presence of domestic cats in the horses' environment was identified as a risk factor associated with infection. This was expected, since cats are the definitive hosts of $T$. gondii and excrete oocysts into the environment. This forms the main means of infection for herbivores, given their dietary habits (AGANGA et al., 1983; TENTER et al., 2000; FERGUSON, 2009; DUBEY, 2010). The oocysts can be spread around the environment through wind, rain and surface water. Although hay, straw and grains were not evaluated as possible risk factors in the present study, these have already been identified as factors associated with infection among horses (ALVARADO-ESQUIVEL et al., 2012).

In the current study, presence of rats in the horses' environment was associated with higher positivity for $T$. gondii, since rats are natural hosts for $T$. gondii and are common prey for cats. Their presence in the environment may promote closure of the biological cycle, with excretion of millions of oocysts into the environment.

Consumption of lagoon water also appeared to be a risk factor in the present study. Lagoons are sources of stagnant water and this may explain why consumption of this water was a risk factor. This water may contain elevated concentrations of oocysts, given that they may remain viable for months or years in water or damp earth (TENTER et al., 2000). Oocysts resist temperature variations and a wide variety of disinfectants, which makes it impractical to attempt to destroy oocysts in large reservoirs of water (DUBEY, 2010).

Two large-scale outbreaks of human toxoplasmosis, in Canada and Brazil, were epidemiologically associated with oocyst contamination of drinking water (BOWIE et al., 1997; ARAMINI et al., 1999). This proves the efficiency of T. gondii transmission through contaminated water.

Age was not a factor associated with infection, and this finding corroborated what has been seen in the majority of studies carried out among horses (GARCIA et al., 1999; HAJIALILO et al., 2010; KARATEPE et al., 2010; ALVARADO-ESQUIVEL et al., 2012; GARCÍA-BOCANEGRA et al., 2012). In other species, studies have shown that age is a risk factor, but this generally does not occur with horses. One hypothesis for this is the difference in handling, given that horses start to be trained or mastered from an early age and frequent the same pastures and environments as adult horses, while cows, sheep, goats and pigs are separated into groups according to age for breeding, raising and finishing. Lastly, there was no explanation in the literature for finding that absence of goats was a possible risk factor for infection among horses.

In the light of the above, the high level of positivity that was found indicated that environmental contamination by oocysts was occurring. Therefore, there is a need for preventative measures such as avoidance of the presence of domestic cats close to the 
rearing areas, pastures and sources of water used by equids. The widespread distribution of positive animals also indicated that the possibility of infection among other domestic animals and in humans also exists, through the contaminated environment. Finally, it is probable that donkeys and mules continue to present detectable titers for longer. Further studies are needed to confirm this possibility.

\section{Acknowledgements}

To Fundação de Amparo à Pesquisa do Estado da Bahia (FAPESB) for funding the Project ( $n^{\circ}$ RED 0020/2013) and to Coordenação de Aperfeiçoamento de Pessoal de Nível Superior (CAPES) for the fellowship.

\section{References}

Aganga AO, Kwanashie GG, Belino ED. Toxoplasma antibodies in Polo Horses of Nigeria. Int J Zoonoses 1983; 10(2): 155-158. PMid:6676339.

Al-Khalidi NW, Dubey JP. Prevalence of Toxoplasma gondii Infection in Horses.J Parasitol 1979; 65(2): 331-334. http://dx.doi.org/10.2307/3280181. PMid:448624.

Alvarado-Esquivel C, Rodríguez-Peña S, Villena I, Dubey JP. Seroprevalence of Toxoplasma gondii Infection in Domestic Horses in Durango State, Mexico. J Parasitol 2012; 98(5): 944-945. http://dx.doi.org/10.1645/ GE-3174.1. PMid:22559329.

Aramini JJ, Stephen C, Dubey JP, Engelstoft C, Schwantje H, Ribble CS. Potential contamination of drinking water with Toxoplasma gondii oocysts. Epidemiol Infect 1999; 122(2): 305-315. http://dx.doi.org/10.1017/ S0950268899002113. PMid:10355797.

Bates D, Mächler M, Bolker B, Walker S. Fitting linear mixed-effects models using lme4. J Stat Softw 2015; 67(1): 1-48. http://dx.doi. org/10.18637/jss.v067.i01.

Bowie WR, King AS, Werker DH, Isaac-Renton JL, Bell A, Eng SB, et al. Outbreak of toxoplasmosis associated with municipal drinking water. Lancet 1997; 350(9072): 173-177. http://dx.doi.org/10.1016/S01406736(96)11105-3. PMid:9250185.

Brasil. Ministério da Saúde. Secretaria de Vigilância em Saúde. Doenças infecciosas e parasitárias: guia de bolso [online]. 8. ed. Brasília: Departamento de Vigilância Epidemiológica; 2010 [cited 2010 Aug 01]. Available from: http://bvsms.saude.gov.br/bvs/publicacoes/doencas_infecciosas_ parasitaria_guia_bolso.pdf

Dohoo I, Martin W, Stryhn H. Veterinary epidemiologic research. Charlottetown: University Prince Edward Island; AVC Inc Press; 2003

Dubey JP, Desmonts G. Serological responses of equids fed Toxoplasma gondii oocysts. Equine Vet J 1987; 19(4): 337-339. http://dx.doi. org/10.1111/j.2042-3306.1987.tb01426.x. PMid:3622463.

Dubey JP. The history of Toxoplasma gondii-The first 100 years. J Eukaryot Microbiol 2008; 55(6): 467-475. http://dx.doi.org/10.1111/j.15507408.2008.00345.x. PMid:19120791.

Dubey JP. Toxoplasmosis of animals and humans. 2nd ed. Boca Raton: CRC Press; 2010.
El-Ghaysh A. Seroprevalence of Toxoplasma gondii in Egyptian donkeys using ELISA. Vet Parasitol 1998; 80(1): 71-73. http://dx.doi.org/10.1016/ S0304-4017(98)00177-0. PMid:9877073.

Evers F, Garcia JL, Navarro IT, Zulpo DL, Nino BSL, Ewald MPC, et al. Diagnosis and isolation of Toxoplasma gondii in horses from Brazilian slaughterhouses. Rev Bras Parasitol Vet 2013; 22(1): 58-63. http://dx.doi. org/10.1590/S1984-29612013005000009. PMid:23538498.

Ferguson DJP. Toxoplasma gondii: 1908-2008, homage to Nicolle, Manceaux and Splendore. Mem Inst Oswaldo Cruz 2009; 104(2): 133-148. http:// dx.doi.org/10.1590/S0074-02762009000200003. PMid:19430635.

Food and Agriculture Organization of The United Nations - FAO. La Comisión Europea propone reforzar los controles sobre la carne de caballo y vacuno [online]. Rome: FAO; 2013 [cited 2013 Apr 10]. Available from: http://www.fao.org/agronoticias/agro-noticias/detalle/es/?dyna_ fef\%5Bbackuri\%5D=21174\&dyna_fef\%5Buid $\% 5 \mathrm{D}=170018$

Garcia JL, Navarro IT, Ogawa L, Oliveira RC. Soroprevalência do Toxoplasma gondii, em suínos, bovinos, ovinos e eqüinos, e sua correlaçáo com humanos, felinos e caninos, oriundos de propriedades rurais do norte do Paraná-Brasil. Cienc Rural 1999; 29(1): 91-97. http://dx.doi. org/10.1590/S0103-84781999000100017.

García-Bocanegra I, Cabezón O, Arenas-Montes A, Carbonero A, Dubey JP, Perea A, et al. Seroprevalence of Toxoplasma gondii in equids from Southern Spain, 2012. Parasitol Int 2012; 61(3): 421-424. http://dx.doi. org/10.1016/j.parint.2012.02.003. PMid:22366344.

Ghazy AA, Shaapan RM, Abdel-Rahman EH. Comparative serological diagnosis of toxoplasmosis in horses using locally isolated Toxoplasma gondii. Vet Parasitol 2007; 145(1-2):31-36. http://dx.doi.org/10.1016/j. vetpar.2006.11.010. PMid:17174034.

Hajialilo E, Ziaali N, Fasihi Harandi M, Saraei M, Hajialilo M. Prevalence of anti-Toxoplasma gondii antibodies in sport horses from Qazvin, Iran. Trop Anim Health Prod 2010; 42(7): 1321-1322. http://dx.doi.org/10.1007/ s11250-010-9576-4. PMid:20383793.

Haridy FM, Saleh NM, Khalil HH, Morsy TA. Anti-Toxoplasma gondii antibodies in working donkeys and donkey's milk in greater Cairo, Egypt. J Egypt Soc Parasitol 2010; 40(2): 459-464. PMid:21246953.

Jakubek EB, Lundén A, Uggla A. Seroprevalences of Toxoplasma gondii and Neospora sp. infections in Swedish horses. Vet Parasitol 2006; 138(3-4): 194-199. http://dx.doi.org/10.1016/j.vetpar.2006.02.002. PMid:16517077.

Karatepe B, Babür C, Karatepe M, Kiliç S. Seroprevalence of toxoplasmosis in horses in Niğde Province of Turkey. Trop Anim Health Prod 2010; 42(3): 385-389. http://dx.doi.org/10.1007/s11250-009-9430-8. PMid:19701805.

Lopes AP, Sousa S, Dubey JP, Ribeiro AJ, Silvestre R, Cotovio M, et al. Prevalence of antibodies to Leishmania infantum and Toxoplasma gondii in horses from the North of Portugal. Parasit Vectors 2013; 6: 178-182. http://dx.doi.org/10.1186/1756-3305-6-178. PMid:23773870.

Marques LC, Costa AJ, Lopes CWG, Lacerda JC No. Experimental toxoplasmosis in pregnant mares: Clinical signs, parasitemia and immunological observations. Semina: Ciênc Agrár 1998; 19(1): 45-49. http://dx.doi.org/10.5433/1679-0359.1998v19n1p45.

Mendonça ADO, Cerqueira EJL, Araujo WN, Silva EM, Shimabukuro $\mathrm{FH}$, Sarkis DT, et al. Inquérito sorológico para toxoplasmose em equídeos procedentes de duas regiōes do Estado da Bahia, Brasil. Semina: Ciênc Agrár 2001; 22(2): 115-118. http://dx.doi.org/10.5433/16790359.2001v22n2p115. 
Pomares C, Ajzenberg D, Bornard L, Bernardin G, Hasseine L, Dardé ML, et al. Toxoplasmosis and horse meat, France. Emerg Infect Dis 2011; 17(7): 1327-1328. http://dx.doi.org/10.3201/eid1707.101642. PMid:21762609.

R Development Core Team. R: a language and environment for statistical computing [online]. Vienna: R Foundation for Statistical Computing; 2016 [cited 2016 July 10]. Available from: https://www.R-project.org/

Saqib M, Hussain MH, Sajid MS, Mansoor MK, Asi MN, Fadya A, et al. Sero-epidemiology of equine toxoplasmosis using a latex agglutination test in the three metropolises of Punjab Pakistan. Trop Biomed 2015; 32(2): 276-285. PMid:26691256.

Shaapan RM, Ghazy AA. Isolation of Toxoplasma gondii from horse meat in Egypt. Pak J Biol Sci 2007; 10(1): 174-177. http://dx.doi.org/10.3923/ pjbs.2007.174.177. PMid:19070010.
Starkweather J. Linear mixed effects modelling using $R$ [online]. 2010 [cited 2013 Aug 9]. Available from: http://researchsupport.unt.edu/class/Jon/ Benchmarks/LinearMixedModels_JDS_Dec201

Tenter AM, Heckeroth AR, Weiss LM. Toxoplasma gondii: from animals to humans. Int J Parasitol 2000; 30(12-13): 1217-1258. http://dx.doi. org/10.1016/S0020-7519(00)00124-7. PMid:11113252.

Vidotto O, Kano FS, Freire RL, Mitsuka R, Ogawa L, Bonesi G, et al. Ocorrência de anticorpos anti-Toxoplasma gondii em eqüinos procedentes de quatro estados (SP, PR, MS e MT) abatidos em Apucarana,PR. Semina: Ciênc Agrár 1997; 18(1): 9-13.

Yang N, Mu MY, Yuan GM, Zhang GX, Li HK, He JB. Seroprevalence of Toxoplasma gondii in slaughtered horses and donkeys in Liaoning province, northeastern China. Parasit Vectors 2013; 6(1): 140. http:// dx.doi.org/10.1186/1756-3305-6-140. PMid:23680297. 